\title{
UJI KINERJA GENERATOR PMG 5 KW PADA TURBIN PEMBANGKIT LISTRIK ARUS LAUT
}

\section{KW Permanent Magnet Generator (PMG) Performance's Testing of Marine Current Turbine}

\author{
Afian Kasharjanto ${ }^{1}$ dan Eko Marta Suyanto ${ }^{1}$ \\ ${ }^{1}$ Balai Teknologi Hidrodinamika, Surabaya. \\ Email: afian.kasharjanto@gmail.com
}

Diterima: 20 Januari 2015; Direvisi: 4 Mei 2015; Disetujui: 29 Oktober 2015

\begin{abstract}
Abstrak
Optimalisasi luaran listrik yang dihasilkan adalah merupakan tujuan utama dari desain turbin arus laut. Berbeda dengan listrik yang dihasilkan oleh PLN, luaran listrik turbin arus laut bersifat tidak stabil karena putaran generator sangat tergantung pada energi kinetik arus laut sebagai sumber awal untuk memutar generator. Dikarenakan kecepatan arus laut yang diterima tidak bersifat konstan (selalu berubah) maka putaran generator juga selalu berubah. Disamping itu, luaran listrik yang dihasilkan oleh generator bisa jadi tidak sesuai dengan spesifikasi teknis yang di infokan dari pabrikan. Uji kelistrikan generator ini bertujuan untuk mengetahui gambaran sampai sejauh mana kinerja operasional Permanent Magnet Generator (PMG) $5 \mathrm{~kW}$ pada saat mendapatkan gaya dari putaran rotor. Uji coba dilaksanakan di Bengkel Mekanik BTH melalui uji variasi beban dan putaran. Hasil uji coba berupa data tegangan (V), arus listrik (I) dan daya listrik (P).
\end{abstract}

Kata kunci: uji kelistrikan, generator PMG 5 kW, efisiensi

\begin{abstract}
Electricity optimization is the main objective in the designning of marine current energy turbine. Unlike electricity from national electricity company, the electricity output from marine current turbine is unstable just because the generator rotation (rpm) is un-stable due to unstability of the marine current movement. Besides, electricity output from generator could not be the same as the specification from manufacturer. That's why generator performance's testing is essencial to be done. Objective of the generator testing is to get the picture of generator performance PMG $5 \mathrm{~kW}$ when it works on site. Testing was conducted in our workshop through testing variation of electrical load dan rotation $(\mathrm{rpm})$. Test result can be voltage $(V)$, electricity current $(I)$ and electricity power $(P)$.
\end{abstract}

Keywords: electrical testing, generator PMG $5 \mathrm{~kW}$, efficiency

\section{PENDAHULUAN}

Proses kegiatan pengembangan desain turbin arus laut di BTH telah mencapai tahap optimalisasi luaran listrik yang dihasilkan. Kegiatan yang sudah di mulai sejak 2006 ini berdasarkan data hasil uji coba prototipe di Jembatan Suramadu tahun 2013, kegiatan selanjutnya difokuskan pada bagaimana cara untuk bisa meningkatkan effisiensi luaran listrik generator yang artinya agar energi putaran rotor turbin dapat di serap se-optimal mungkin untuk di konversi menjadi energi listrik. Melalui mekanisme sistem transmisi poros mekanik dengan rasio putaran tertentu, putaran akan di teruskan ke generator sehingga menghasilkan listrik. Prinsip kerja ini sangat sederhana karena hanya di butuhkan perhitungan desain sistem transmisi mekanik dengan rasio putaran tertentu sehingga bisa mencapai jangkauan putaran kerja generator minimum dan maksimum. Generator tidak akan bisa berputar apabila putaran di bawah nilai putaran minimal generator begitu juga akan terbakar apabila putaran 
generator melebihi putaran maksimal. Batasan inilah yang harus bisa dicapai dalam melakukan desain sistem transmisi. Meskipun sejak tahun 2010 uji coba turbin di laut selalu menghasilkan listrik, tetapi listrik yang dihasilkan masih di bawah kemampuan kapasitas generator yang di gunakan. Tetapi karena pada saat tersebut masih di fokuskan pada target listrik harus menyala, maka pertimbangan optimalisasi luaran listrik menjadi hal yang dapat di kembangkan pada tahap berikutnya.

Berbicara mengenai prospek pengembangan dan pemanfaatan energi terbarukan dari sumber arus laut, maka sumber energi arus laut di Indonesia paling potensial untuk di kembangkan dalam skala yang lebih besar lagi. Jika dijumlahkan dari seluruh potensi selat-selat di seluruh perairan Indonesia, hasil survei dan perhitungan numerik menunjukkan bahwa secara teoritis potensi energi yang dapat di panen sangat besar, dari 10 (sepuluh) lokasi yang sebagian besar ada di wilayah Indonesia timur diperkirakan memiliki potensi 3000 Mega Watt (Erwandi, 2011). Di seluruh dunia, diperkirakan dapat menghasilkan 3.17 Terra Watt hanya dari sumber energi arus laut saja (Kantha, 2000).. Sumber energi ini dapat dengan mudah diprediksi karena terjadinya arus laut hanya tergantung pada interaksi gaya tarik menarik antara bumi-bulan-matahari yang secara terus menerus berlangsung selamanya (Gitrio, Tanpa Tahun).

\section{METODOLOGI}

Metodologi yang dilaksanakan adalah melalui pengujian luaran listrik generator PMG $5 \mathrm{~kW}$ di bengkel mekanik dengan cara generator di putar oleh motor listrik sesuai dengan jangkauan putaran yang ada pada data spesifikasi teknis generator (240-480 rpm). Pengujian terdiri 2 (dua) jenis pengujian:

1. Uji kelistrikan generator tanpa beban

2. Uji kelistrikan generator berbeban langsung dengan inverter

Pada saat uji kelistrikan dengan beban, setiap putaran diberikan variasi beban listrik (pemasangan lampu), mulai 100 Watt sampai dengan 2400 Watt. Pada setiap tahapan proses uji coba akan di catat data-data sebagai berikut : frekuensi motor, putaran motor (rpm), putaran generator (rpmgen), beban lampu (watt), arus listrik generator dan tegangan generator. Data-data tersebut kemudian dibandingkan dengan spesifikasi teknis dari produsen generator.

\section{PROSES UJI COBA}

Grafik generator PMG $3.5 \mathrm{~kW}$ yang di gunakan dalam uji coba turbin arus laut adalah sebagai berikut:
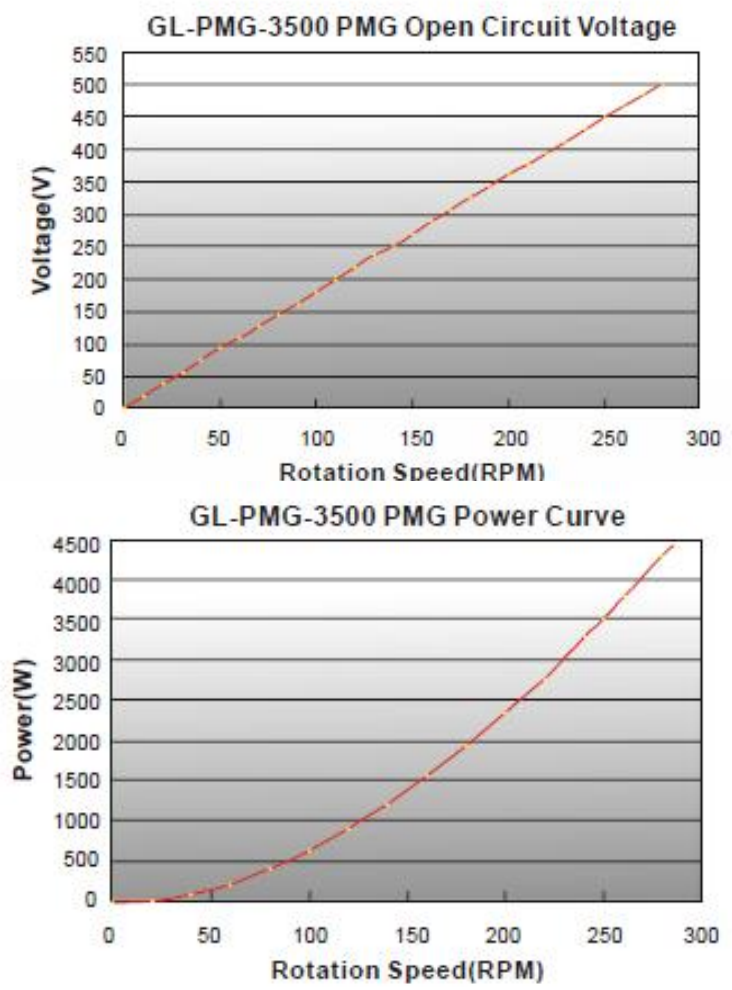

Grafik di atas adalah sebagai acuan untuk mengetahui kinerja generator yang akan di uji.

\section{Uji Kelistrikan Generator Tanpa Beban}

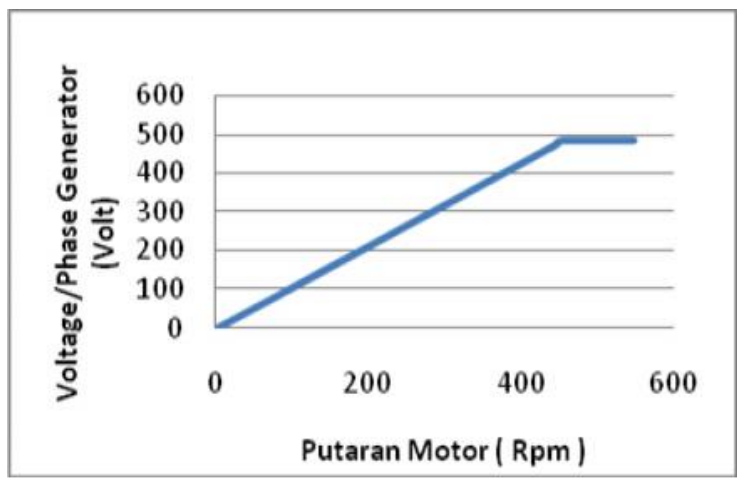

Gambar 3. Grafik kenaikan tegangan generator pada uji generator tanpa beban 
Prinsip uji putaran generator adalah dengan cara memutar generator (rpm) dengan bantuan motor listrik mulai dari putaran terndah sampai dengan posisi putaran generator maksimum, yaitu posisi dimana tegangan generator tidak dapat bertambah lagi meskipun putaran di tambah grafik di bawah ini menunjukkan nilai tegangan generator sebagai fungsi dari putaran (rpm).

\section{Uji Kelistrikan Generator Beban Langsung}

Prinsip kerja uji coba ini sama dengan uji coba sebelumnya, yaitu generator di putar dengan bantuan motor listrik pada tiap-tiap variasi putaran. Selanjutnya tegangan listrik generator yang dihasilkan akan di distribusikan langsung kebeban-beban peralatan listrik secara bertahap mulai dari beban yang terkecil sampai dengan beban maksimum (sampai generator tidak bisa berputar lagi/error) dengan menggunakan lampu bohlam masing-masing $100 \mathrm{Watt}$.

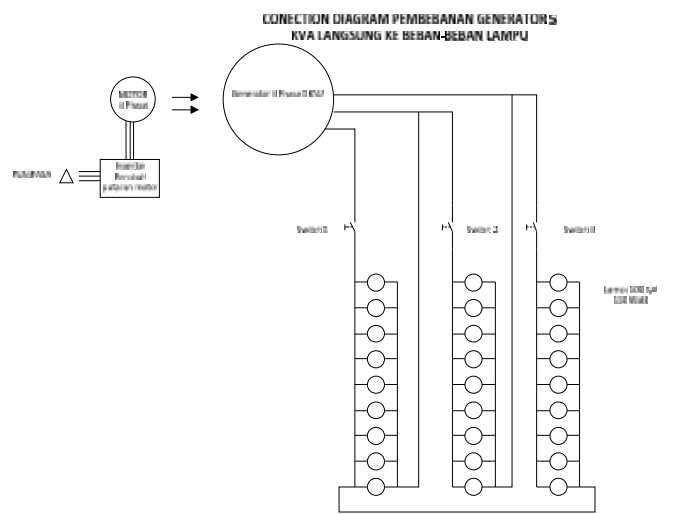

Gambar 4. Diagram sistem pembebanan generator

Langkah pengujian :

1) Setting putaran pada inverter pengubah putaran motor sehingga didapat putaran motor yang diinginkan.

2) Memutar motor pada rpm yang ditentukan sehingga generator berputar pada rpm yang diinginkan dengan perbandingan putaran $1: 3$.

3) Jika generator berputar pada rpm yang diinginkan maka akan diberikan beban output kelistrikan mulai dari yang terkecil sampai dengan yang terbesar. Disini kita pakai beban terkecil dengan lampu bolam berdaya 200 Watt sampai dengan 450 Watt.

4) Pendataan besaran putaran generator (rpm) yang tetap dengan besaran beban yang berbeda-beda (Watt) sehingga diperoleh gambaran dengan putaran generator yang ditentukan akan menghasilkan penurunan atau kenaikan level rotasi dari generator. Pada langkah ini dilakukan pencatatan data tegangan sebagai fungsi dari penambahan beban generator pada tiap tiap data putaran generator.

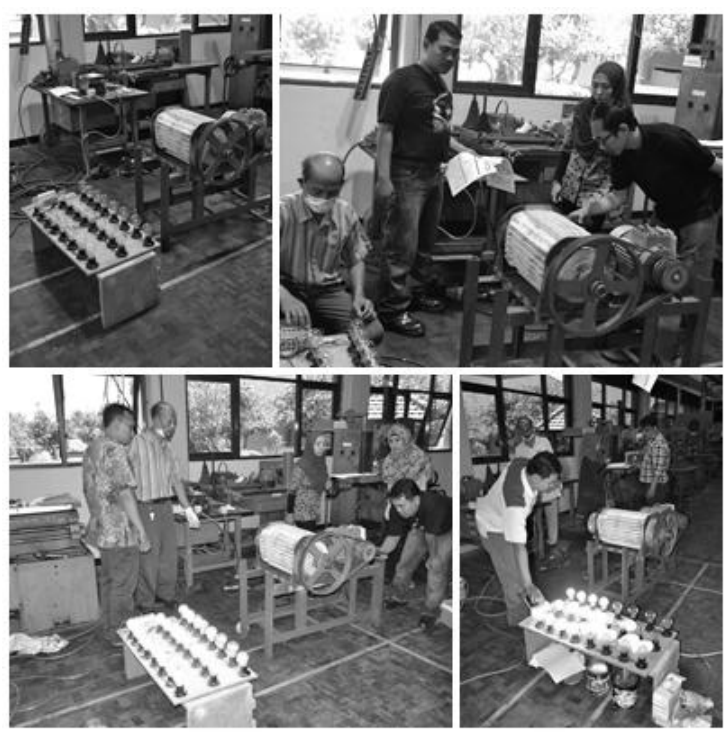

Gambar 5. Proses uji kelistrikan generator beban langsung

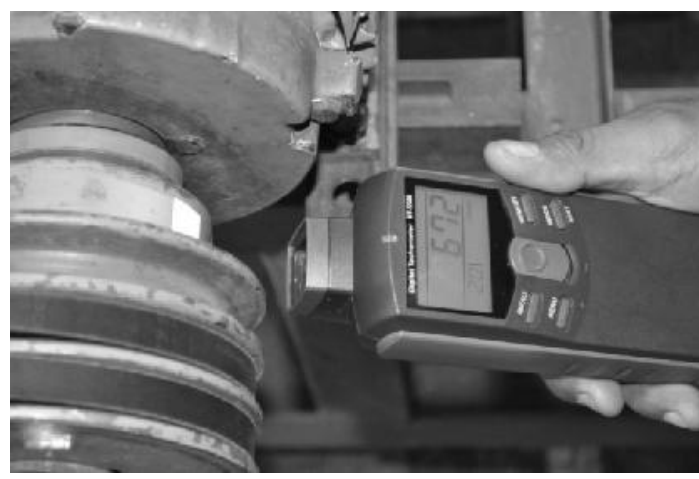

Gambar 6. Pengukuran putaran generator menggunakan tacho

meter

Pada metode pengujian ini, dikarenakan tegangan maksimum lampu adalah 220 Volt AC, sehingga uji coba beban tidak dapat di tingkatkan sampai melebihi tegangan maksimum (menyebabkan beban lampu akan terputus) sehingga pengujian tidak dapat terus dilakukan sampai melebihi tegangan maksimum sehingga pada pengujian ini tidak efektif untuk melihat efisiensi generator. 


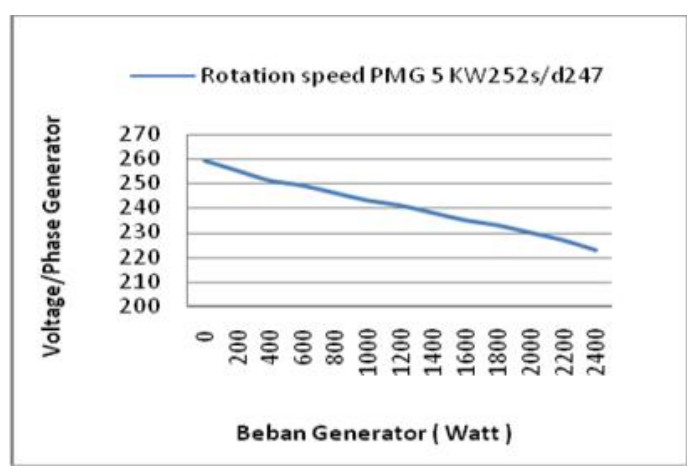

Gambar 7. Data pengujian generator $5 \mathrm{~kW}$ beban langsung

\section{HASIL DAN PEMBAHASAN}

Dari hasil pengujian generator ada beberapa hal yang perlu mendapat perhatian sebagai berikut:

1. Dari data uji generator tanpa beban diketahui bahwa semakin besar putaran generator nilai tegangan akan semakin besar pula sampai pada batas nilai maksimal putaran. Selanjutnya nilai tegangan akan konstan meskipun putaran generator di tambah. Nilai tegangan maksimum sebesar 482 Volt AC terjadi pada putaran rpm mulai 485 keatas.

2. Tegangan generator yang bisa diberikan adalah pada nilai 220 Volt AC saja, karena di atas nilai tersebut akan menyebabkan lampu putus.

3. Daya maksimum di dapat pada putaran generator $300 \mathrm{rpm}$.

4. Jika di bandingkan dengan grafik dari pabrikan generator Ginlong (Gambar 1), dapat di lihat bahwa pola penambahan nilai tegangan bersifat hiperbolik sedangkan pada hasil uji generator didapat bahwa pola grafik penambahan nilai tegangan bersifat linier. Sedangkan nilai tegangan maksimum antar keduanya relatif sama, yaitu sekitar 485 sampai 490 Volt

\section{KESIMPULAN}

Pada nilai putaran maksimal $300 \mathrm{rpm}$, tegangan yang dihasilkan 300 Volt dan arus listrik 5.4 Ampere, daya (P) yang dihasilkan 1706.4 Watt. Hal ini menunjukkan bahwa efisiensi generator hanya sekitar 50\% dari kapasitas maksimumnya. Penyebabnya diduga karena usia penggunaan generator yang sudah 4 (empat) tahun dan telah mengalami beberapa perbaikan sehingga kinerja generator sudah tidak sesuai dengan kondisi pada saat masih baru.

\section{DAFTAR PUSTAKA}

Erwandi. (2011). The Development of Indonesian Vertical Axis Marine Current Turbine for Tidal Power Generation, World Renewable Energy Congress - Indonesia, Bali Nusa Dua Convention Center, 17 - 19 Oktober 2011.

Gitrio, Agung. (Tanpa Tahun). Pembangkit Listrik Tenaga Pasang. (http://www.academia.edu/5385793).

Kantha, L. H. dan Clayson, C. A. (2000). Numerical Models of Oceans and Oceanic Processes, Academic Press, USA.

Kasharjanto, Afian, Nurhadi, dan Pitoyo. (2012). Uji Coba Prototipe Turbin Arus Laut di Jembatan Suramadu, Jurnal Wave Vol. 6, Nomor 2.

Myers, L. E. dan Bahaj, A. S. (2005). Simulated Electrical Power Potential Harnessed by Marine Current Turbine Arrays at the Alderney Race, Renewable Energy 30(11):1713-1731. 